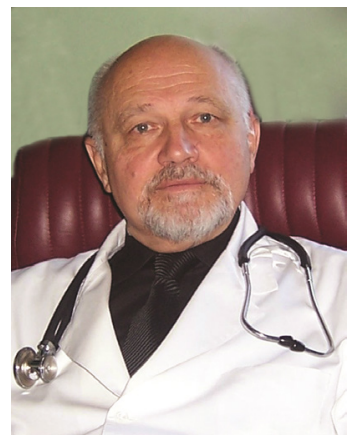

O. Abrahamovych, M. Abrahamovych, S. Tolopko, M. Ferko, O. Fayura

Danylo Halytsky Lviv National Medical University

\title{
State of the Autonomic Nervous System in Patients with the Different Severity Stages of Cirrhosis of the Liver
}

A problem of the occurrence and course of liver cirrhosis (LC) and its severity increase is one of the most difficult in modern gastroenterology. An important place in the pathogenesis of LC, the course of the disease and its prognosis takes the state of the autonomic nervous system (ANS), however its features, in spite of its important role in the human organism, are not sufficiently studied. It is known that ANS provides activity of internals, adjusting the vascular tone, innervation of the internal secretion glands, trophic innervation of the skeletal muscles, receptors and nervous system. Co-operating with the endocrine and somatic nervous systems, it provides the maintenance of constancy of the homoeostasis and adaptation to the variable terms of the environment $[8,11]$. According to the different sources, autonomic disorders can be met in $85.0 \%$ of the patients with viral hepatitis B, in $72.0 \%$ - with alcoholic liver disease, in $71.0 \%$ - with primary biliary cirrhosis, in $58.0 \%$ - with viral hepatitis $\mathrm{C}$, in $46.0 \%$ - with primary sclerosing cholangitis $[5,12-15]$.

The information about the ANS disorders in patients with chronic diffuse liver lesions in the literature however is often fragmentary, contradictory and is based on the smallish quantity of clinical material. All functionaldynamic indices of the ANS state are not taken into consideration - this is the defect of many works. This fact highly limits the possibility of achievement of the reliable diagnosis and prognosis of the disease course, especially in patients with LC. Some information about the results of ANS study in patients with LC can be found in the works of Y. Kondo et al. [16], L. Coelho et al. [13], but the comprehensive study of its state in cirrhotic patients taking into the account the severity according to the $\mathrm{C}$. G. Child-R. N. Pugh's criteria have not been conducted. A value of the ANS role is extraordinarily important, because its disorders deepen the severity of the disease course. It is predetermined by the exclusion of the central mechanisms of adjusting with passing to the lowest level of regulation - humoral-metabolic, that is prognostically an unfavorable sign.

Aim. The aim of our study was to find out the ANS state in cirrhotic patients with the different degree of the severity.

Objects and study methods. The study was conducted in accordance with the standarts of Helsinki Declaration (1964, review - 2008). In addition, the procedures were approved by the local Ethics Committee. Into the study, in a randomized manner, there were attracted 93 patients with liver cirrhosis (age from 30 to 65 years, 63 men $(67.7 \%)$ and 30 women $(32.3 \%)$ ), without concomitant disorders of the cardiovascular system. They were examined and treated in the Lviv Regional Hepatological Center, created on the base of Internal Medicine Department № 1 of Danylo Halytsky Lviv National Medical University and Gastroenterological Department of Lviv Regional Clinical Hospital (LRCH) and were consulted by neurologist. Therefore, patients were stratified by the criteria of C. G. Child-R. N. Pugh and were divided into three groups -23 persons $(24.7 \%)$ belonged to the group of compensated LC (class A), $47(50.6 \%)$ - to the group of subcompensated LC (class B) and $23(24.7 \%)$ patients - to the group of decompensated LC (class $\mathrm{C}$ ). That testifies the possibility of a 10-year survival of 25.0, 7.0 and $0.0 \%$ persons correspondingly. The control group (CG) was made of 15 practically healthy volunteers of the same sex and age.

For the verification of the diagnosis, except for the routine clinical-laboratory and instrumental investigations (by the order of Ministry of Health of Ukraine N 271 dated 13 Jun 2005), the estimation of the ANS state was conducted. The determination of the basic functionaldynamic indices of the ANS state: tone, autonomic reactivity, autonomic providing of the organism activity, using A. M. Wein's questionnaire [17], clinical criteria of A. D. Solovyov [17], functional tests: thermal, cold, TomRoux's, orthoclinostatic probes [17], and registration of heart variability rate (HVR) were conducted. The analysis of the HVR was based on the estimation of the R-R-intervals 
durations on ECG in I, II and AVF leads, consecutive cycles of the cardiac beat during five minutes in lying position (before the physical activity) and six minute in standing position (after the physical activity) - orthostatic test conducted on the computer electrocardiograph "PolySpectr" with the software "Neurosoft" (Ivanovo, Russia) according to the standarts of Working Group of the European Cardiology Society and North-American Society of Cardiostimulation and Electrophysiology [1-4, 16]. Received information was added to the specially created thematic patient card, located in the computer database and was statistically worked up by "Excel 2010". To compare the samples with normal distribution, we used Student's t-criterion and two parts comparison method. Bonding force between variables was determined according to the K. Pirson's coefficient $-r$. Received results were presented as $\mathrm{M} \pm \mathrm{m}, \mathrm{n}$ - the amount of the examined patients in the group. Statistically reliable was the following difference: $p<0.05$.

Results. The first step of our study was to estimate the autonomic tone in cirrhotic patients by the analysis of the complaints and conducting medical examination. Consequently, according to the results of A. M. Wein's questionnaire [17], the most often symptoms of the autonomic disorders were met in the patients of $\mathrm{C}$ class (by C. G. Child-R. N. Pugh), the sum of the collected points of which exceeded the indices of the $\mathrm{CG}$ on 72.0 $\%(\mathrm{p}<0.001)$, and in patients of classes B and A - on $62.5 \%(\mathrm{p}<0.001)$ and $53.3 \%(\mathrm{p}<0.001)$, accordingly. The difference of the points, made in classes: between $\mathrm{C}$ and $A-67.0 \%(p<0.001), B$ and $A-24.7 \%(p<0.01)$, $\mathrm{C}$ and $\mathrm{B}-33.9 \%(\mathrm{p}<0.01)$, with a tendency to increase with the growth of the severity class (Fig. 1).

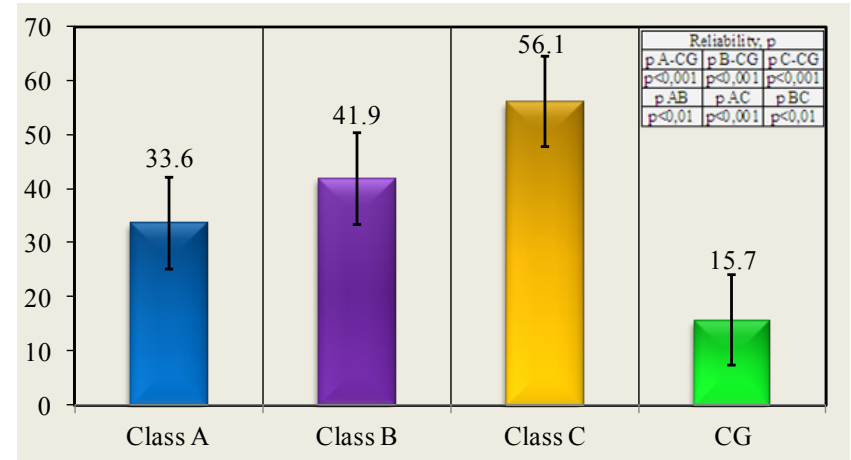

Fig. 1. Frequency of the autonomic disorders in cirrhotic patients depending on the prevalence of the pathological process in the liver according to the results of A. M. Wein's questionnaire.

According to the results of the medical examination, in obedience to the criteria of A. D. Solovyov [17], the tone of the sympathetic nervous system (SNS) prevailed in all groups of the patients: for the persons of class $\mathrm{A}-$ on $30.0 \%, \mathrm{~B}-$ on $44.0 \%, \mathrm{C}-$ on $51.6 \%$ and for the $\mathrm{CG}$ - on $3.0 \%$, comparing with the tone of the parasympathetic nervous system (PSNS). In comparison with the $\mathrm{CG}$, the sum of the collected points which characterizes sympathicotonia, for the patients of class
A was bigger by $51.1 \%(\mathrm{p}<0.01), \mathrm{B}-$ by $63.6 \%$ $(p<0.001), C-$ by $75.6 \%(p<0.001)$, and the sum of the points, which characterizes parasympathicotonia: for the persons of class A - by $56.3 \%(\mathrm{p}<0.01), \mathrm{B}-$ by $47.2 \%(\mathrm{p}<0.05), \mathrm{C}-$ by $50.0 \%(\mathrm{p}<0.01)$. The differences in points between classes were: between $\mathrm{A}$ and $\mathrm{B}-$ $7.6 \%(\mathrm{p}<0.001)$ and $6.2 \%(\mathrm{p}<0.001), \mathrm{A}$ and $\mathrm{C}-13.9$ $\%(\mathrm{p}<0.05)$ and $4.2 \%, \mathrm{~B}$ and $\mathrm{C}-6.8 \%(\mathrm{p}<0.001)$ and $1.9 \%(p<0.001)$ comparatively to the points which characterize the tone of the SNS and PSNS, accordingly, with the tendency to hypertone of the SNS in case of the disease decompensation. It testifies the activating of the compensatory possibilities of the organism, directed on the homoeostasis maintenance in case of the appearance of portal hypertension (Fig. 2).

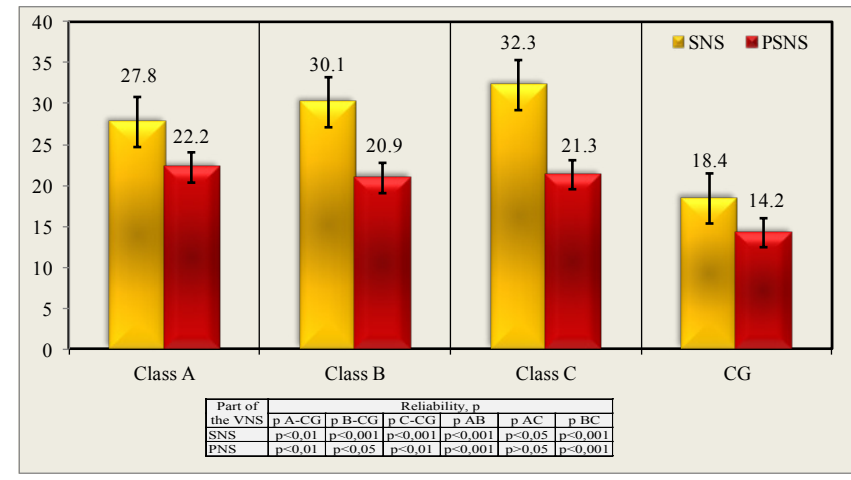

Fig. 2. Frequency of the autonomic disorders in cirrhotic patients depending on the prevalence of pathological process in the liver according to the clinical criteria of A. D. Solovyov.

Consequently, the conducted studies have allowed us to diagnose the disorders of ANS in all the patients with LC, severity of which significantly increases with the disease decompensation. In all the people SNS tone has prevailed with a tendency to hypertone with increasing of the pathological process severity, indicating the activation of compensatory capacity of the organism to maintenance homeostasis in case of portal hypertension.

The second step of our study was the estimation of the autonomic reactivity, by the method of the origin study in reply to the internal and external irritants. For this purpose we used such tests: cold, thermal, Tom-Roux's (epigastric reflex) and orthoclinostatic probes [17].

Results, received after the conducting of cold test, testify, that comparatively to the $\mathrm{CG}$, in most persons of class A $(91.3 \%)$ hyperreactivity of the ANS is diagnosed more frequently $(\mathrm{p}<0.001)$, that is in 74.5 and $91.3 \%$ of the persons of classes B and C accordingly ( $p<0.001)$. The autonomic reactivity reliability decreases collateral with the increase of C. G. Child-R. N. Pugh's class. So, only in $25.5 \%$ of the persons of class B hyperreactivity of the ANS was diagnosed, - it is considerably rarer in comparison to the class A, where in $74.5 \%$ of the patients the hyporeactivity was diagnosed $(\mathrm{p}<0.001)$. In $91.3 \%$ of the patients, belonging to class $C$ relatively more frequent hyporeactivity was found, compared to the A $(p<0.001)$ and $B(p<0.05)$ classes, in $8.7 \%$ patients of the $C$ class - pathological reactivity was observed. Hyperreactivity 
of the ANS was not found in any of the patients, that testifies the exhaustion of the compensatory activation of the SNS. The results of thermal, orthoclinostatic, Tom-

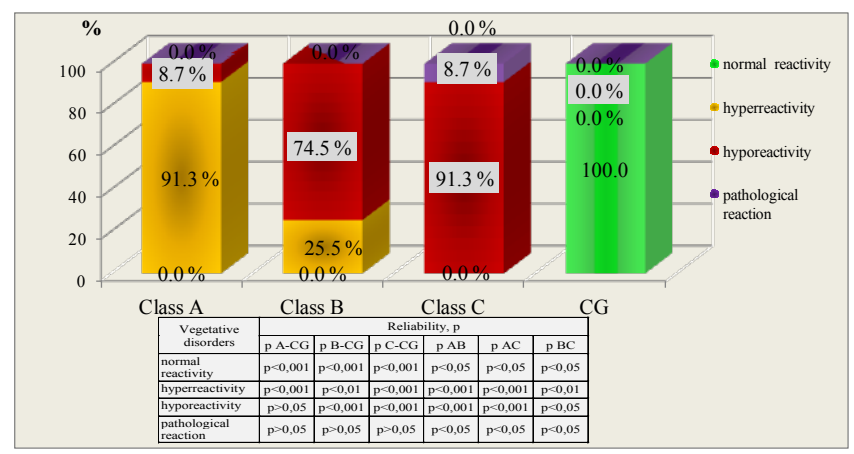

Fig. 3. Frequency of the autonomic disorders in cirrhotic patients depending on the prevalence of pathological process in the liver according to the results of the cold test.
Roux's probes confirm the indices, got during the conducting of the cold test (Fig. 3).

The results of the thermal, orthoclinostatic and TomRoux's tests were confirmed by the indices, received during the cold test.

The third step of our study was devoted to the attempt of the estimation of the level of organism adaptation and tension of the basic regulatory systems, sympathetic-parasympathetic balance and the state of the heart nervous adjusting system on the basis of exact measuring of the objective indices by the method of the registration of the HVR. For this purpose we have studied the spectral indices of the HVR, such as: TP (total power), VLF \% (the percent of the very low frequency), LF \% (the percent of the low frequency), HF \% (the percent of the high frequency) (Table 1) $[1-4,6,7,9,10,16]$.

Table 1

Meanings of the indices of heart variability rhythm spectral analysis in cirrhotic patients, divided into different classes by C. G. Child-R. N. Pugh's criteria

\begin{tabular}{|c|c|c|c|c|c|c|c|c|c|c|c|c|}
\hline \multirow{3}{*}{$\mathrm{N}$} & \multirow{3}{*}{\multicolumn{2}{|c|}{ HVR indices }} & \multicolumn{3}{|c|}{$\begin{array}{l}\text { Classes according to } \\
\text { C. G. Child-R. N. Pugh's } \\
\text { criteria }\end{array}$} & \multirow{3}{*}{$\begin{array}{c}\mathrm{CG}, \\
\mathrm{n}=15 \\
\mathrm{M} \pm \mathrm{M}\end{array}$} & \multicolumn{6}{|c|}{ Reliability, p } \\
\hline & & & \multirow{2}{*}{$\begin{array}{c}\mathrm{A}, \\
\mathrm{n}=23 \\
\mathrm{M} \pm \mathrm{M}\end{array}$} & \multirow{2}{*}{$\begin{array}{c}\mathrm{B} \\
\mathrm{n}=47 \\
\mathrm{M} \pm \mathrm{M}\end{array}$} & \multirow{2}{*}{$\begin{array}{c}\mathrm{C}, \\
\mathrm{n}=23 \\
\mathrm{M} \pm_{\mathrm{M}}\end{array}$} & & \multirow{2}{*}{$\mathrm{pA}-\mathrm{CG}$} & \multirow{2}{*}{$\mathrm{pB}-\mathrm{CG}$} & \multirow{2}{*}{$\mathrm{pC}-\mathrm{CG}$} & \multirow{2}{*}{$\mathrm{pAB}$} & \multirow{2}{*}{$\mathrm{pAC}$} & \multirow{2}{*}{$\mathrm{pBC}$} \\
\hline & & & & & & & & & & & & \\
\hline \multirow{2}{*}{1} & \multirow{2}{*}{$\begin{array}{c}\mathrm{TP}, \mathrm{mc}^{2} / \\
\mathrm{Hz}\end{array}$} & $\begin{array}{l}\text { before the } \\
\text { physical } \\
\text { activity }\end{array}$ & $\begin{array}{c}923.4 \\
\pm 191.3\end{array}$ & $\begin{array}{c}935.9 \\
\pm 139.4\end{array}$ & $\begin{array}{l}203.4 \\
\pm 46.2\end{array}$ & $\begin{array}{r}3243.8 \\
\pm 301.9\end{array}$ & $\mathrm{p}<0.001$ & $\mathrm{p}<0.001$ & $\mathrm{p}<0.001$ & $\mathrm{p}>0.05$ & $\mathrm{p}<0.001$ & $\mathrm{p}<0.001$ \\
\hline & & $\begin{array}{l}\text { during the } \\
\text { physical } \\
\text { activity }\end{array}$ & $\begin{array}{l}725.6 \\
\pm 153.5\end{array}$ & $\begin{array}{r}1051.8 \\
\pm 197.3\end{array}$ & $\begin{array}{c}336.4 \\
\pm 83.0\end{array}$ & $\begin{array}{c}2784.7 \\
\pm 564.0\end{array}$ & $\mathrm{p}<0.001$ & $\mathrm{p}<0.001$ & $\mathrm{p}<0.001$ & $\mathrm{p}>0.05$ & $\mathrm{p}<0.05$ & $\mathrm{p}<0.01$ \\
\hline \multirow{2}{*}{2} & \multirow{2}{*}{ VLF, \% } & $\begin{array}{c}\text { before the } \\
\text { physical } \\
\text { activity }\end{array}$ & $\begin{array}{r}53.6 \\
\pm 3.0\end{array}$ & $\begin{array}{l}55.5 \\
\pm 2.5\end{array}$ & $\begin{array}{r}64.9 \\
\pm 3.4\end{array}$ & $\begin{array}{l}37.1 \\
\pm 3.8\end{array}$ & $\mathrm{p}<0.001$ & $\mathrm{p}<0.001$ & $\mathrm{p}<0.001$ & $\mathrm{p}>0.05$ & $\mathrm{p}<0.01$ & $\mathrm{p}<0.05$ \\
\hline & & $\begin{array}{l}\text { during the } \\
\text { physical } \\
\text { activity }\end{array}$ & $\begin{array}{r}69.5 \\
\pm 3.7\end{array}$ & $\begin{array}{r}61.9 \\
\pm 3.0\end{array}$ & $\begin{array}{r}80.7 \\
\pm 3.1\end{array}$ & $\begin{array}{r}37.9 \\
\pm 3.9\end{array}$ & $\mathrm{p}<0.001$ & $\mathrm{p}<0.001$ & $\mathrm{p}<0.001$ & $\mathrm{p}>0.05$ & $\mathrm{p}<0.01$ & $\mathrm{p}<0.01$ \\
\hline \multirow[t]{2}{*}{3} & \multirow{2}{*}{$\mathrm{LF}, \%$} & $\begin{array}{c}\text { before the } \\
\text { physical } \\
\text { activity }\end{array}$ & $\begin{array}{l}25.9 \\
\pm 2.0\end{array}$ & $\begin{array}{l}25.6 \\
\pm 1.5\end{array}$ & $\begin{array}{l}20.6 \\
\pm 2.1\end{array}$ & $\begin{array}{r}34.6 \\
\pm 3.3\end{array}$ & $\mathrm{p}<0.01$ & $\mathrm{p}<0.01$ & $\mathrm{p}<0.001$ & $\mathrm{p}>0.05$ & $\mathrm{p}<0.05$ & $\mathrm{p}<0.05$ \\
\hline & & $\begin{array}{l}\text { during the } \\
\text { physical } \\
\text { activity }\end{array}$ & $\begin{array}{l}22.5 \\
\pm 2.5\end{array}$ & $\begin{array}{l}25.3 \\
\pm 1.8\end{array}$ & $\begin{array}{r}13.8 \\
\pm 3.0\end{array}$ & $\begin{array}{l}46.5 \\
\pm 3.1\end{array}$ & $\mathrm{p}<0.001$ & $\mathrm{p}<0.001$ & $\mathrm{p}<0.001$ & $\mathrm{p}>0.05$ & $\mathrm{p}<0.05$ & $\mathrm{p}<0.01$ \\
\hline \multirow{2}{*}{4} & \multirow{2}{*}{$\mathrm{HF}, \%$} & $\begin{array}{c}\text { before the } \\
\text { physical } \\
\text { activity }\end{array}$ & $\begin{array}{l}20.5 \\
\pm 2.7\end{array}$ & $\begin{array}{l}19.0 \\
\pm 2.4\end{array}$ & $\begin{array}{r}14.6 \\
\pm 2.5\end{array}$ & $\begin{array}{l}28.3 \\
\pm 3.6\end{array}$ & $\mathrm{p}<0.05$ & $\mathrm{p}<0.05$ & $\mathrm{p}<0.001$ & $\mathrm{p}>0.05$ & $\mathrm{p}<0.05$ & $\mathrm{p}<0.05$ \\
\hline & & $\begin{array}{l}\text { during the } \\
\text { physical } \\
\text { activity }\end{array}$ & $\begin{array}{c}8.0 \\
\pm 1.9\end{array}$ & $\begin{array}{r}12.9 \\
\pm 2.1\end{array}$ & $\begin{array}{c}5.4 \\
\pm 1.1\end{array}$ & $\begin{array}{l}15.6 \\
\pm 4.1\end{array}$ & $\mathrm{p}<0.001$ & $\mathrm{p}>0.05$ & $\mathrm{p}<0.01$ & $\mathrm{p}>0.05$ & $\mathrm{p}>0.05$ & $\mathrm{p}<0.01$ \\
\hline
\end{tabular}

As can be seen from table 1, during the record of the HVR without stress the indices of the general spectral power (TP), in patients of class A $(923.4 \pm$ $\left.191.3 \mathrm{mc}^{2} / \mathrm{Hz}\right), \mathrm{B}\left(935.9 \pm 139.4 \mathrm{mc}^{2} / \mathrm{Hz}\right)$ and $\mathrm{C}(203.4$ $\left.\pm 301.9 \mathrm{mc}^{2} / \mathrm{Hz}\right)$ were significantly $(\mathrm{p}<0.001)$ lower than in the CG $\left(3243.8 \pm 46.2 \mathrm{mc}^{2} / \mathrm{Hz}\right)$. In the patients of class $C$ the indices of TP were significantly lower comparing with class $\mathrm{A}(\mathrm{p}<0.001)$ and $\mathrm{B}(\mathrm{p}<0.001)$ with the tendency to the decrease with the increase of severity class. It testifies the strengthening of the SNS influence, however not reflect the structure of the organism regulation levels. To improve this fact, the correlative connections between the values of TP index and the classes of LC, taking into account the amount of points according to the C. G. Child-R. N. Pugh's criteria, were detected and the reccurent correlative 
connection of the weak power $(\mathrm{r}=-0.4 ; \mathrm{p}<0.001)$ was found.

Studying the influence of neuro-humoral factors on an organism in a percentage ratio (VLF \%), it was shown, that for the patients of class A this index was significantly higher compared to the CG $(\mathrm{p}<0.001)$. And in cirrhotic patients of the $\mathrm{C}$ class $(64.9 \pm 3.4 \%)$ it was higher than in the classes $\mathrm{A}(53.6 \pm 3.0 \%, \mathrm{p}<0.01)$ and $\mathrm{B}(55.5 \pm$ $2.5 \%, p<0.05)$ with the tendency to increase with the increase of the pathological process severity. It testifies the decrease of the role of the ANS central mechanisms with passing to the lowest - humoral-metabolic level of the organism adjusting. There is the direct correlative connection of weak power $(r=0.2 ; p<0.01)$ between the mentioned index and the classes of $\mathrm{LC}$ according to the C. G. Child-R. N. Pugh's criteria.

Estimating the influence of the SNS in the structure of the general spectrum (LF \%) it was determined, that it was considerably less in the patients of class A (25.9 $\pm 2.0 \%, \mathrm{p}<0.01), \mathrm{B}(25.6 \pm 1.5 \%, \mathrm{p}<0.01)$ and $\mathrm{C}(20.6$ $\pm 2.1 \%, \mathrm{p}<0.001)$ comparatively to the group of practically healthy volunteers $(34.6 \pm 3.3 \%)$, and also in class $\mathrm{C}$ compared to class A $(p<0.05)$ and B $(p<0.05)$. Received results confirm, that in general autonomic tone, neuro- humoral influences prevail with the increase of the LC severity and it was found the reccurent correlative connection of weak power too $(\mathrm{r}=-0.2 ; \mathrm{p}<0.01)$.

Characterizing the activity of the PSNS, according to results of the HF \% index, the hypotony was found in all the cirrhotic patients. Its percent value was lower in classes A $(20.5 \pm 2.7 \%, \mathrm{p}<0.05), \mathrm{B}(19.0 \pm 2.4 \%, \mathrm{p}<0.05)$ and $\mathrm{C}(14.6 \pm 2.5 \%, \mathrm{p}<0.001)$, than in the CG $(28.3 \pm$ $3.6 \%$ ); and in the patients of the $\mathrm{C}$ class compared to the same index in the classes A $(p<0.05)$ and $B(p<0.05)$. So, with the increase of the LC severity class the value of $\mathrm{HF} \%$ decreases, that is confirmed by the study of the correlative connections $(r=-0.2 ; p<0.01)$.

The results, got during the conducting of the orthostatic test, confirm the indices, got before the stress.

Conclusions. In $100.0 \%$ of the patients there were found the disorders of the ANS with the predominance of the sympathetic branch of the ANS over parasympathetic influences, which increase with the decompensation of the disease with directly proportional growth of the neurohumoral influences in accordance with the severity of the pathological process in the liver according to the C. G. Child-R. N. Pugh's criteria.

\section{References}

1. Analysis of the cardiac rhythm variability in the clinical practice (age-specific aspects) / O. V. Korkushko, A. V. Pisaruk, V. B. Shatulo [et al.]. - K.: Institute of Gerontology of AMSU, 2002. - P. 30-65.

2. Babunz I. V. The alphabet of the cardiac rhythm variability analysis / I. V. Babunz, E. V. Miradzanyan, Y. A. Mashaeh. - Stavropol, 2002. - 112 p.

3. Baevskij R. M. Introduction into the prenosological diagnosis / R. M. Baevskij, A. P. Berseneva. - M.: Slovo, 2008. - N 2. -220 p.

4. Baevskij R. M. The evaluation of adaptative facilities and risk of disease development / R. M. Baevskij, A. P. Berseneva. - M., 1997. - Vol. 1, N 4. - P. 56-58.

5. Frith J. Autonomic dysfunction in chronic liver disease / J. Frith, L. Newton // Hepatic Medicine: Evidence and Research. - 2011. - Vol. 3, N 1 - P. 81-87.

6. Hayutin V. M. Spectral analysis of the heart rate variability: physiological basis and complications / V. M. Hayutin, E. V. Lukoshkova // Russian Physiol. J. - 1999. - Vol. 85, N 7. - P. 893-908.

7. Hemorheology and heart rate variability: is there a relationship / P. Connes, O. Hue, M. Hardy-Dessources [et al.] // Clin. Hemorheol. Microcirc. - 2008. - Vol. 38, N 2. - P. 257-265.

8. Lezenko H. O. The influence of the metabolic disorders on the status of the autonomic regulation of the cardiac activity / H. O. Lezenko, O. I. Podlianova, O. M. Chakmazova // Health of Ukraine. - 2005. - N 114. - P.44-52.

9. Malik M. Components of heart rate variability - what they really mean and what we really measure / M. Malik, A. Camm // Amer. J. Cardiol. - 1993. - Vol. 72, N 11. - P. 821-822.

10. Malliani A. Heart rate variability: from bench to bedside / A. Malliani // Europ. J. Int. Med. - 2005. - Vol. 16, N 7. - P. 12-20.

11. Omelyanchik V. M. Characteristics of the neuro-autonomic regulation of the cardiac activity in children of the primary school age in the conditions of the industrial region / V. M. Omelyanchik, O. A. Zuravlova // Zaporozkyj Med. J.- 2011. - Vol. 13, N 2. - P. 36-42.

12. Palibroda N. M. Pathogenic grounding of the differential treatment of gastric mucous membrane lesions in patients with liver cirrhosis: autoreferat of the dissertation for obtaining the scientifical degree of the candidate of medical science: spec. 14.01.36 / Gasroenterology / Palibroda N. M. - Ivano-Frankivsk, 2007. - 13 p.

13. Podymova S. D. Liver diseases / S. D. Podymova. - M.: Medicine, 1998. - 213 p.

14. Ryabokon E. V. Indices of the cardiac rhythm variability and the content of the catecholamines in blood erythrocytes in patients with different forms of hepatitis C / E. V. Ryabokon, Y. M. Kolesnik // Modern Infections. - 2003. Vol. 4. - P. 28-33.

15. Ryabokon $\mathrm{E}$. V. Indices of the cardiac rhythm variability in the patients with chronic hepatitis $\mathrm{C}$ with the different activity of the transferring enzymes in blood serum / E. V. Ryabokon, Y. M. Kolesnik // Zaporozkyj Med. J. 2004.- Vol. 1, N 1. - P. 14-17. 
16. Standarts of measurement, physiological interpretation and clinical use. Task Force of the European Society of Cardiology and the North American Society of Pacing and Electrophysiology // Europ. Heart J. - 1996. Vol. 9, N 17. - P. 354-381.

17. Autonomic disorders / ed. A. M. Wein, T. H. Voznesenskaya [et al.]. - M.: Medical information agency, 2008. $-749 \mathrm{p}$.

Стаття надійшла до редакції журналу 11 листопада 2014 р.

\title{
Стан вегетативної нервової системи у хворих на цироз печінки різного ступеня важкості
}

\section{О. О. Абрагамович, М. О. Абрагамович, С. Я. Толопко, М. Р. Ферко, О. П. Фаюра}

Порушення стану вегетативної нервової системи $є$ одним із патогенетичних механізмів виникнення та наростання важкості цирозу печінки через виключення центральних механізмів регуляції життєвих процесів із переходом на найнижчий рівень - гуморально-метаболічний, що $є$ несприятливою прогностичною ознакою.

3 метою оцінки стану вегетативної нервової системи нами проведено комплексне клініко-лабораторне обстеження 93 хворих на цироз печінки. Вивчено їі основні функціонально-динамічні показники: тонус, вегетативну реактивність, вегетативне забезпечення діяльності організму. Використано опитувальник А.М. Вейна, клінічні критерії А.Д. Соловйова, функціональні проби: теплову, холодову, Тома - Ру, ортокліностатичну, а також реєстрацію варіабельності серцевого ритму. Отримані результати дали змогу діагностувати наявність вегетативних порушень у 100,0 \% пацієнтів, причому з переважаючими впливами симпатичного відділу вегетативної нервової системи над парасимпатичним із прямо пропорційним зростанням нейрогуморальних впливів відповідно до важкості патологічного процесу в печінці. Вивчення кореляційних зв'язків між показниками варіабельності серцевого ритму і класами цирозу печінки, за С. G. Child R. N. Pugh, дає підставу рекомендувати їх для прогнозування перебігу захворювання.

Ключові слова: вегетативна нервова система, цироз печінки, вегетативна реактивність.

\section{State of the Autonomic Nervous System in Patients with the Different Severity Stages of Cirrhosis of the Liver}

\author{
O. Abrahamovych, M. Abrahamovych, S. Tolopko, M. Ferko, O. Fayura
}

It is known that the disorders of the autonomic nervous system state is one of the pathogenetic mechanisms of the appearance and increase of the severity of liver cirrhosis, due to the exclusion of the central regulatory mechanisms of life processes with the transition to the lowest level - humoral-metabolic, which is an unfavorable prognostic sign.

In order to assess the state of the autonomic nervous system we have conducted a comprehensive clinical and laboratory examination of 93 patients with cirrhosis and studied its basic functional and dynamic indices: tone, autonomic reactivity, autonomic support of the organism functioning, using the questionnaire of A. M. Wein, clinical criteria of A. D. Solovyov, functional tests: thermal, cold, Tom-Roux, orthoclinostatic and registration of heart rate variability. The results allowed us to diagnose the presence of autonomic disorders in $100.0 \%$ of the patients, with the superior effects of the sympathetic part of the autonomic nervous system over the parasympathetic with the directly proportional increase of the neuro-humoral effects according to the severity of the pathological process in the liver. The study of the correlation between the indices of heart rate variability and classes of liver cirrhosis by C. G. Child-R. N. Pugh lets us recommend them to predict the disease course.

Keywords: autonomic nervous system, liver cirrhosis, autonomic reactivity. 